ECLETICA A A

Volume 28 (2003) número 1

$\underline{\text { www.scielo.br/eq }}$

\title{
POTENTIOMETRIC DETERMINATION OF CAPTOPRIL IN PHARMACEUTICAL FORMULATIONS
}

\author{
P. R. da S. RIBEIRO ' ; A. O. SANTINI ${ }^{2}$; H. R. PEZZA ${ }^{l}$; L. PEZZA ${ }^{2}$
}

\begin{abstract}
A simple, precise, rapid and low-cost potentiometric method for captopril determination in pure form and in pharmaceutical preparations is proposed. Captopril present in tablets containing known quantity of drug was potentiometrically titrated in aqueous solution with $\mathrm{NaOH}$ using a glass $\mathrm{pH}$ electrode, coupled to an autotitrator. No interferences were observed in the presence of common components of the tablets as lactose, microcrystalline cellulose, croscarmellose sodium, starch and magnesium stearate. The analytical results obtained by applying the proposed method compared very favorably with those obtained by the United States Pharmacopoeia Standard procedure. Recovery of captopril from various tablet dosage formulations range from 98.0 to $102.0 \%$.
\end{abstract}

Keywords: potentiometric determination; captopril; pharmaceutical formulations.

\section{Introduction}

Captopril, chemically know as 1-[(2S)-3mercapto-2-methylpropionyl]-L-proline, (CPT) is used therapeutically as an antihypertensive agent $[11,15]$, which is also prescribed for the treatment of congestive hart failure [6].

Several types of analytical procedures have been proposed for the analysis of captopril in pharmaceuticals formulations. These procedures include capillary electrophoresis [13], high-performance liquid chromatography (HPLC) [3, 4, 5, 9], polarography [10], voltammetry [23], coulometry [20], amperometry [18], conductometry [19], fluorimetry [12], colorimetry $[1,2,7,14,22,24]$ and flow injection methods.[12, 21, 28]. Some of the- ses procedures are not simple for routine analysis and required expensive or sophisticated instruments.

Potentiometric methods with ion-selective membranes electrodes (ISE's) can provide valuable and straightforward means of assaying captopril in pharmaceutical formulations because of the possibility to determine directly the active ions in the solution. ISEs' low-cost, easy of use and maintenance, and the simplicity and speed of assay procedure, and the reliability of the analytical information make them very attractive for the assay of pharmaceutical products.

Potentiometric methods based in the reactivity of thiol group have been used for captopril determination in pharmaceutical formulations $[8$,

\footnotetext{
${ }^{1}$ Departamento de Química Analítica - Instituto de Química - UNESP - CEP 14801-970 - Araraquara - SP - Brasil.

${ }^{2}$ Departamento de Química Orgânica - Instituto de Química - UNESP - CEP 14801-970 - Araraquara - SP - Brasil.
} 
17, 26].

To the best of our knowledge, despite the advantages of the glass membrane $\mathrm{pH}$ electrode, there are no previous reports for the potentiometric determination of captopril based in the reactivity of this carboxyl group using the glass $\mathrm{pH}$ electrode.

For this reason, the purpose of this work was to develop a potentiometric method for direct determination of captopril in tablet dosage formulations. The method is based in a potentiometric titration of captopril (carboxyl group) in aqueous solutions with sodium hydroxide solution using a combined glass electrode, coupled to an autotitrator. The proposed method is simple, rapid, precise, accurate and inexpensive.

The results agreed fairly well with those obtained by the United States Pharmacopoeia (USP) standard procedure [27] (iodimetric titration). The influence of interferents normally found along with captopril in tablet dosage formulations in also studied.

\section{Experimental}

\section{Apparatus}

Potentiometric measurements were carried out using a Metrohm autotitrator, model 716 (Metrohm Ltd., Herisau, Switzerland). The indicator electrode was a Metrohm combined $\mathrm{pH}$ electrode model 60234.100. A thermostated titration cell (25.0 \pm 0.1$) \mathrm{OC}$ was employed. Volume measurements $( \pm 0.001 \mathrm{~mL})$ were performed with a Metrohm automatic burettes model 665 .

\section{Reagents}

All chemicals were analytical grade and solutions were prepared with deionized water (conductivity $=18.2 \mathrm{M} \Omega \mathrm{cm}$ ). Captopril (standard substance) was purchased from sigma (St Louis, MO, USA). It was analysed as prescribed in the USP [27] and contains $99.7 \%$ of $1-[(2 \mathrm{~S})-3$-mercapto-2methylpropionyl]-L-proline, calculated with reference to the dried substance. It was used as a standard. The captopril tablets $(25 \mathrm{mg})$ manufactured respectively by Medley (Campinas, Brazil), Azupharma Gmbh (Gerlingen, Germany) and
Apotex (Toronto, Canadian) were used for the analysis. Sodium hydroxide and sodium nitrate were purchased from Merck (Darmstadt, Germany).

\section{Solutions}

A freshly prepared $1.000 \times 10^{-1} \mathrm{~mol} \mathrm{~L}^{-1}$ aqueous of solutions of captopril (standard substance) was used as the stock solution.

The sodium hydroxide $2.00 \times 10^{-2} \mathrm{~mol} \mathrm{~L}^{-1}$ was prepared, standardized and stored according to recommendation of the literature [25].

The ionic strength (I) of the final solutions used for the potentiometric determination was kept constant at $0.500 \mathrm{~mol} \mathrm{~L}^{-1}$ by addition of sodium nitrate.

\section{Recommended procedures}

\section{For pure form}

A standard solution $(100 \mathrm{~mL})$ of captopril $1,000 \times 10-2 \mathrm{~mol} \mathrm{~L}^{-1}$ (I adjusted to $0.500 \mathrm{~mol} \mathrm{~L}^{-1}$ with $\mathrm{NaNO}_{3}$ ) was prepared by suitable dilution of the stock solution with water.

An aliquot of $15.000 \mathrm{~mL}$ of this solution was transferred to a thermostated glass cell $(25.0 \pm 0.1)^{\circ} \mathrm{C}$ and potentiometrically titrated with a standard solution of $\mathrm{NaOH} 2.00 \times 10^{-2} \mathrm{~mol} \mathrm{~L}^{-1}(\mathrm{I}=$ $0.500 \mathrm{~mol} \mathrm{~L}^{-1}$ in $\mathrm{NaNO}_{3}$ ).

\section{Tablets analysis}

Fifteen tablets were weighed to calculate the average tablet weight. They were finely powdered and homogenized. A portion of the powder equivalent to about $217.3 \mathrm{mg}$ of captopril was accurately weighed and dissolving with $40 \mathrm{~mL}$ of water by sonicating for $20 \mathrm{~min}$ in an ultrasonic bath. The resulting mixture was filtered and its ionic strength was adjusted to $0.500 \mathrm{~mol} \mathrm{~L}^{-1}$ with $\mathrm{NaNO}_{3}$. Finally, this solution was diluted with water in a $100 \mathrm{~mL}$ flask and analysed under the same procedure described for captopril in pure form.

\section{Results and discussion}

Ecl. Quím., São Paulo, 28(1): 33-44, 2003 


\section{Potentiometric titration}

The development of the titration curves of polyprotic acids depends on the absolute and relative values of the respective stepwise ionization constants. Theoretically, there will be one inflection for each labile hydrogen. However, so that an inflection is associated to an adequate variation in $\mathrm{pH}$, it is necessary in the first place for the relationship of the respective ionization constant to the next one to be greater than $10^{4}\left(\mathrm{~K}_{1} / \mathrm{K}_{2}>10^{4}\right.$ or $\left.\mathrm{pk}_{2}-\mathrm{pk}_{1}>4\right)$. In the second place, it is necessary for the corresponding ionization constant not to be that of a very weak acid.

Captopril is dibasic acid having dissociation constants $\mathrm{pk}_{1}=3.7$ (carboxyl group) and $\mathrm{pk}_{2}=$ 9.8 (thiol group). Observing the values of $\mathrm{pk}_{1}$ and $\mathrm{pk}_{2}$ of captopril, it can be foreseen that the titration curve presents a clear inflection for the first point of equivalence since $\mathrm{k}_{1}=2 \times 10^{-4}$ and the relationship of $\mathrm{k}_{1} / \mathrm{k}_{2}=10^{6}\left(\mathrm{pk}_{2}-\mathrm{pk}_{1}=6\right)$. However, captopril is a very weak acid in relation to its second hydrogen $\left(\mathrm{k}_{2} \quad 10^{-10}\right)$ that its titration curve does not present a perceivable inflection for the second point of equivalence.

Figure 1 (a) shows a typical potentiometric titration curve with only one inflection point. In the proposed method changes at the titration end point were enough pronounced to give potentiometric titration curves of satisfactory shape for an accurate and reproducible end point detection. The time required for the analyses of captopril (after the samples preparation) in tablet dosage formulations by potentiometric method was $8 \mathrm{~min}$. per sample.

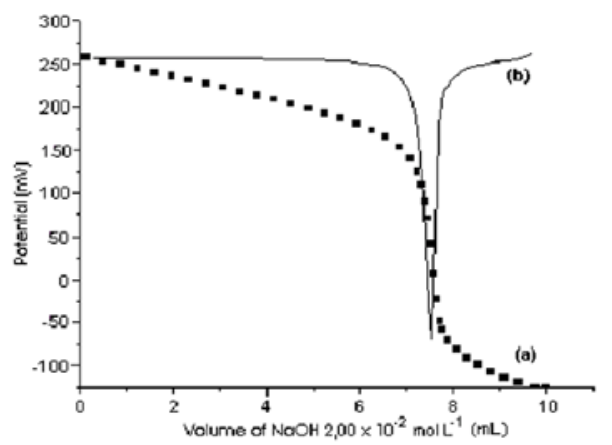

Figure 1. (a) typical potentiometric titration curve of captopril (sample A) with $\mathrm{NaOH}$ solution; (b) first derivative plot supplied by the autotitrator.

Ecl. Quím., São Paulo, 28(1): 33-44, 2003
Figure 1(b) shows the first derivative of the potentiometric titration curve generated by the internal algorithm of the autotitrator. The evaluation of the potentiometric titration curve by the autotitrator is fully automatic yielding an accurate end point. The determination limit of the proposed method determined as described by Leite [16] was $180 \mathrm{~g} \mathrm{~mL}^{-1}$.

\section{Effect of interferents}

To assess the usefulness of the proposed method, the effect of the common components (additives, adjuvants and excipients), which often accompany captopril in tablet formulations (lactose, microcrystalline cellulose, croscarmellose sodium, starch and magnesium stearate) were investigated in a concentration range of least 20 times higher than that of captopril. No interferences were observed in the presence of the substances tested.

\section{Analytical applications}

The proposed method was successfully applied for captopril determination in tablet formulations. The results presented in Table 1, agreed fairly well with those obtained by the USP standard procedure [27] (iodimetric titration).

For further confirmation, the standard addition method was applied to test the reliability and recovery of the proposed method. The recovery studies were carried out after adding known quantities of the standard substance (pure drug) to the preanalyzed formulations. The results presented in Table 2 show that the percentage recoveries were found to be close to $100 \%$; the SDs were within $0.48-$ 0.85 . These results point out the accuracy and precision of the method and the absence of significant matrix effects on potentiometric measurements at least for the samples analysed. 


\begin{tabular}{|c|c|c|c|c|c|c|c|c|}
\hline \multirow[t]{2}{*}{ Sample } & \multirow[t]{2}{*}{ Manufacturer } & \multirow{2}{*}{\begin{tabular}{|l|} 
Label to \\
content
\end{tabular}} & \multicolumn{6}{|c|}{ Proposed method } \\
\hline & & & Found & $\%$ & $\begin{array}{c}\text { RST }^{d} \\
\left({ }^{d}\right) \\
(n=5)\end{array}$ & Found $^{c}$ & so & $\begin{array}{c}\text { RSI })^{4} \\
(\%) \\
(n=5)\end{array}$ \\
\hline $\begin{array}{l}\text { Captopril } \\
\text { (pure } \\
\text { form) }\end{array}$ & Sigma & $217.3^{2}$ & $\begin{array}{c}215.3 \pm \\
0.8\end{array}$ & 99.1 & 0.37 & $\begin{array}{c}216.6 \pm \\
0.9\end{array}$ & 99.7 & 0.41 \\
\hline $\begin{array}{l}\text { Captopril } \\
\text { A (tablcts) }\end{array}$ & Mullcy & $25^{k}$ & $24.8 \pm 0.1$ & 99.2 & 0.40 & $25.3 \_0.1$ & 101.2 & 0.39 \\
\hline $\begin{array}{l}\text { Caplopril } \\
\text { B (tablcts) }\end{array}$ & $\begin{array}{c}\text { Neypharma } \\
\text { Gmbh }\end{array}$ & $25^{b}$ & $25.8 \pm 0.2$ & 103.2 & 0.77 & $26.0 \pm 0.2$ & 104.0 & 0.77 \\
\hline $\begin{array}{l}\text { Captopril } \\
\text { C (ublets) }\end{array}$ & Apotex & $25^{b}$ & $25.5 \pm 0.1$ & 102.10 & 0.39 & $25,3=0.1$ & 101.2 & 0.39 \\
\hline
\end{tabular}

Table 1. Determination of captopril in pure form and in pharmaceuticals using the proposed method.

${ }^{\mathrm{a}}$ For the assay of captopril in pure form, an amount equivalent to $217.3 \mathrm{mg}$ of the standard substance (Sigma) was taken.

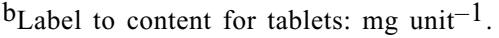

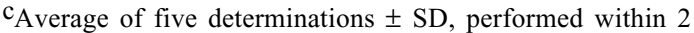
-3 days.

$\mathrm{d}_{\text {Relative standard deviation (RSD) }}$

\begin{tabular}{c|c|c|c}
\hline $\begin{array}{c}\text { Pharmaceutical } \\
\text { Formulations }\end{array}$ & $\begin{array}{c}\text { Added } \\
\left(\mathrm{mg} \mathrm{mL}^{-1}\right)\end{array}$ & $\begin{array}{c}\text { Found } \\
\left(\mathrm{mg} \mathrm{mL}^{-1}\right)\end{array}$ & Recovery $(\%)^{\mathrm{a}}$ \\
\hline Captopil ^ (Mcdlcy) & 1.0 & 0.98 & $98.00 \pm 0.62$ \\
& 2.0 & 2.03 & $101.50 \pm 0.73$ \\
& 4.0 & 4.03 & $100.75 \pm 0.59$ \\
\hline Captopril B & 1.0 & 0.98 & $98.00 \pm 0.85$ \\
(^zupharma Gmbh) & 2.0 & 2.01 & $100.50 \pm 0.48$ \\
& 4.0 & 3.99 & $99.75 \pm 0.65$ \\
\hline Captopril C & 1.0 & 1.02 & $102.00 \pm 0.73$ \\
(Apotex) & 2.0 & 1.98 & $99.00 \pm 0.61$ \\
& 4.0 & 4.04 & $101.00 \pm 0.68$ \\
\hline
\end{tabular}

Table 2. Recovery data for captopril spiked to pharmaceu ${ }^{-}$ ticals. ${ }^{a}$ Average \pm SD of three determinations.

\section{Conclusion}

Compared with many of the already existing procedures for the determination of captopril, which required special instrumentation, reagents, precautions and experience, the propose potentiometric method employing the glass $\mathrm{pH}$ electrode exhibited the advantages of simple operation, reasonable selectivity, fast response, low-cost, and sufficient accuracy for the determination of captopril in pharmaceutical formulations.

\section{Acknowledgements}

We would like to thank FUNDUNESP, CAPES, CNPq and FAPESP Foundations (Brazil) for financial support.

RIBEIRO, P. R. S. et al. Determinação potenciométrica de captopril em formulações farmacêuticas.

\section{Resumo}

Um método potenciométrico simples, preciso, rápido e de baixo custo foi proposto para a determinação de captopril na forma pura e em formulações farmacêuticas. $\mathrm{O}$ captopril presente em comprimidos em uma quantidade conhecida foi potenciometricamente titulado em meio aquoso com um titulador automático, empregando-se como titulante uma solução aquosa de $\mathrm{NaOH}$ e um eletrodo combinado de vidro sensível a $\mathrm{pH}$. Interferências não foram observadas na presença de componentes comumente encontrados nos comprimidos, tais como, lactose, celulose microcristalina, croscarmelose sódica, amido e estearato de magnésio. Os resultados analíticos obtidos a partir da aplicação do método proposto estão em muito boa concordância com aqueles obtidos pelo método oficial descrito na Farmacopéia Americana. O recobrimento obtido para o captopril a partir de um estudo realizado com várias formulações farmacêuticas variou de 98.0 a $102.0 \%$.

Palavras-chave: determinação potenciométrica, captopril, formulações farmacêuticas.

\section{References}

[1] ASHOUR, F. M.; SALAMA, F. M.; AZIZA, M. A. E. A colorimetric method for the determination of captopril. $J$. Drugs Res., v. 19, n. 1-2, p. 323-326, 1990.

[2] ASKAL, H. F. New spectrophotometric methods for determination of captopril bulk drug and tablets. Talanta,

Ecl. Quím., São Paulo, 28(1): 33-44, 2003 
v. 10, p. 1155-1158, 1991.

[3] BALD, E.; SYPNIEWSKI, S. Determination of thiol drugs in pharmaceutical formulations as their 5-pyridinium derivatives by high-performance liquid chromatography with ultraviolet detection. Fresenius J. Anal. Chem., v. 358, n. 4, p. 554-555, 1997.

[4] CAVRINI, V.; GATTI, R.; DIPRETA, A. M.; RAGGI, M. A. Determination of thiol drugs in pharmaceutical formulations using ethacrynic-acid as a precolumn ultraviolet derivatizaon reagent. Chromatographia, v. 23, n. 9, p. 680-683, 1987.

[5] CAVRINI, V.; GATTI, R.; ANDRISANO, V.; GATTI, R. 1,1'-[ethenylidenebis (sulfonyl)] bis-benzene: A useful pre-cromatographic derivatization reagent for HPLC analyses of thiol drugs. Chromatographia, v. 42, n. 9-10, p. 515-520, 1996.

[6] DAVIS, R.; RIBNER, H.; KEUNG, E.; SONNENBLICK, E.; LE-JEMTEL, T. Treatment of chronic congestive heart-failure with captopril, and oral inhibitor of angiotensin converting enzyme. New England J. Med., v. 301, n. 3, p. 117-121, 1979.

[7] EL-ASHRY, S. M.; IBRAHIM, F. A. Colorimetric determination of captopril in dosage forms. Anal. Lett., v. 25, n. 9, p. 1657-1672, 1992.

[8] EL-BRASHY, A. M. Titrimetric determination of captopril in dosage forms. Acta Pharm. Hung., v. 65, n. 3, p. 91-93, 1995.

[9] FAVARO, G.; FIORANI, M. Determination of pharmaceutical thiols by chromatography with electrochemical detection: use of an electrode with conductive carbon cement matrix, chemically modified with cobalt phthalocyanine. Anal. Chim. Acta, v. 332, n. 2-3, p. 249-255, 1996.

[10] FRAGA, J. H. G.; ABIZANDA, A. I. J.; MORENO, F.J.; LEON, J. J. A. Application of principal component regression to the determination of captopril by differential pulse polarography with no prior removal of dissolved oxygen. Talanta, v. 46, n. 1, p. 75-82, 1998.

[11] FIORY, K. Analytical profiles of drugs substances. New York: Academic Press, 1982, v. 11. 81 p.

[12] GUERRERO, R. S.; VIVES, S. S.; CALATAYUD, J. M. Fluorometric determination of captopril by flow injection analysis. Microchem. J., v. 43, p. 176-180, 1991.

[13] HILLAERT, S.; VAN DEN BOSSCHE, W. Determination of captopril and its degradation products by capillary electrophoresis. J. Pharm. Biomed. Anal., v. 21, n. 1, p. 65-73, 1999.

[14] JOVANIVIC, T.; STANOVIC, B.; KORICANAC, Z.
Spectrophotometric investigation on complex-formation of captopril with palladium (II) and its analytical application. J. Pharm. Biomed. Anal., v. 13, n. 3, p. 213-217, 1995.

[15] KOCH-WESTER, J. Angiotensin converting-enzyme inhibitor in refractory hypertension. New England J. Med., v. 299, p. 363-364, 1978.

[16] LEITE, F. Validação em análise química. 3a ed. Campinas: Editora Átomo, 1998.p. 68.

[17] MOHAMED, M. E.; ABOUL - ENEIN, H. Y.; GADKARIEM, E. A. Potentiometric and visual titrimetric methods for analysis of captopril and its pharmaceutical forms. Anal. Lett., v. 16, n. B1, p. 45-55, 1983.

[18] MOHAMED, M. E.; ABOUL - ENEIN, H. Y. Amperometric and conductimetric method for simultaneous determination of captopril and bendroflumethiazide. Anal. Lett., v. 18, n. B20, p. 2591-2603, 1985.

[19] NIKOLIC, K.; VALASEVIC, K. S. Conductometric determination of captopril. Phamazie, v. 44, n. 2, p. 155156, 1989.

[20] NIKOLIC, K.; VALASEVIC, K. S. Coulometric determination of captopril. Acta Pol. Pharm., v. 48, n. 1-2, p. 5-7, 1991.

[21] PALOMEQUE, M. E.; BAND, B. S. F. Flow injection biamperometric determination of captopril. J. Pharm. Biomed. Anal., v. 30, n. 3, p. 547-552, 2002.

[22] SANGHAVI, N. M.; SAMARTH, M. M.; MATHARU, R.; SINGH, P. S. Colorimetric estimation of captopril and its formulations. Indian Drugs, v. 28, n. 4, p. 189-191, 1991.

[23] SARNA, K.; FIJALEK, Z. Voltammetric and electrochemical quartz crystal microbalance study of antithyroid drugs. Chem. Anal., v. 42, n. 3, p. 425-433, 1997.

[24] SASTRY, C. S. P.; SAILAJA, A.; RAO, T. T. Determination of captopril by two simple spectrophotometric methods using oxidative coupling reaction. Pharmazie, v. 46, n. 6, p. 465-457, 1991.

[25] SKOOG, D. A.; WEST, D. M.; HOLLER, F. J. Fundamentals of analytical chemistry. 6th ed. Chicago: Saunders College Publishing,1996. 849 p.

[26] STEFAN R. I.; VAN STADEN, J. F.; ABOUL - ENEIN, H. Y. A new construction for a potentiometric, enantioselective membrane electrode - its utilization to the S-captopril assay. Talanta, v. 48, n. 5, p. 1139-1143, 1999.

[27] UNITED STATES PHARMACOPEIAL CONVEN_ 
TION. The United States pharmacopeia: the national formulary: captopril. 24th ed. Rockville, 2000. p. 296-298.

[28] ZHANG, Z. D.; BAEJENS, W. R. G.; ZHANG, X. R.; VAN DER WAKEN, T. Chemiluminescense flow injection analysis of captopril applying a sensitized rhodamine 6G method. J. Pharm. Biomed. Anal., v. 14, n. 8-10, p. 939945, 1996. 